\title{
Preliminary Notes on the Bionomics of the Amphipod, Corophium volutator Pallas.
}

By

\author{
T. J. Hart, B.Sc.
}

With 4 Figures in the Text.

\section{Introduction and Previous Work.}

The Amphipod Corophium volutator Pallas has been described, mainly from a purely systematic standpoint, under the synonyms $C$. grossipes Linnæus, C. longicorne Latreille, and C. bicaudatum Linneo (Della Valle). Stebbing in his standard work (19) on the Gammaridea, accepts volutator as the earliest, and modern French and Danish authors follow him.

Corophium volutator is found in the greatest abundance on certain mudflats in estuarine areas round the coasts of N.W. Europe, but by no means everywhere. It appears that the nature of the substratum and the salinity of the water are two of the main factors leading to its localized distribution, and accordingly an investigation of the conditions which define its habitat is likely to throw light on some very interesting problems. These notes record the first stages of such an investigation, together with a study of the intimately related problems of the feeding habits and lifecycle of the animal.

It seems that no detailed account of the feeding mechanism of any Amphipod has yet been published; though Hunt (11) gives a short and pithy description of a "filter-feeding" mechanism in Ampelisca. This author classes most of the Amphipoda he deals with as selective deposit feeders, but states that though this is true in so far as they are bottomliving forms, the actual mechanism is probably more often of a type such as would lead to their being classed under his scheme as suspensionfeeders. However, it seems obvious from a study of their appendages that some Amphipoda do not possess a filtering mechanism, while it is highly probable that many more combine the habit of feeding on larger particles with filter feeding, as Cannon has found in several of the lower Malacostraca.

Corophium volutator approaches this last type, though, as would be expected from its peculiar habitat, the feeding methods are somewhat specialised and probably differ in detail from those of Amphipoda generally. 
As regards the life-cycle, Blegvad (3) in his exhaustive study of Gammarus locusta from this standpoint has summarised the scanty observations of previous workers. He gives good reasons for supposing that a life-cycle of a certain type is common to a number of littoral Amphipoda of widely different genera. Several broods are hatched each year, the last brood maturing slowly through the winter and commencing to breed in the following spring. Most of the adult individuals of the previous year die off during the winter, but a few breed again in the late winter and early spring. These species are thus annual or nearly so.

While my material has so far been insufficient for the results to be conclusive, they seem to show a life-cycle of an essentially similar type for Corophium volutator.

Sexton's wonderful work on the moulting and growth stages of Gammarus (16) furnishes the only exact information on these points in the whole of Amphipod literature. Her method is to isolate the just hatched young and collect all the moults from that stage onwards from one individual. Thus this method applies only to animals reared under aquarium conditions. Corophium volutator does not, like Gammarus chevreuxi Sexton, breed all the year round (not, at any rate, in the North), and, as most of my work was done perforce during the winter, I could not, most unfortunately, follow it up on these lines. Enough has been gathered from detailed observations of material obtained at different times of the year, to anticipate most interesting and important results from an investigation of Corophium by this method.

The bulk of this work having been presented as a degree thesis at the University of Leeds, I have to thank Prof. Garstang for permission to publish, also for suggesting the work in the first instance, and for help and encouragement throughout. Through the kindness of Dr. Allen, I was able to carry on the work at the Marine Biological Laboratory at Plymouth for three weeks during April, 1929, and so was able to study Corophium from a widely different locality. I have to thank several members of the staff, in particular Mrs. Sexton, Dr. Orton, and Mr. Ford, for much valuable advice and encouragement, and would like in conclusion to pay tribute to the entire working staff for the great kindness with which I was received.

\section{Material and Methods.}

The bulk of the material on which these observations are based was obtained from Whitby harbour. In April, when working at the Plymouth Laboratory, a few Corophium were obtained from the mud-flat between Ditchend and Southpool lake in the Salcombe estuary, and a fairly abundant material from the Cornish bank of the River Tamar, $\frac{1}{2}$ mile below Calstock, where the dilution is considerable. 
In August, 1929, a rich material of Corophium was found in some of the tidal creeks around Blakeney Point, Norfolk, one batch in distinctly brackish water. Unfortunately I have not yet been able to work up this material in detail, but some information gained has been incorporated in this note.

At Whitby, on the W. side of the low-water channel above the bridge, opposite the L. \& N.E.R. goods yard, there is a wide expanse of moderately soft, uniform, grey mud, traversed by but few small runnels, and uncovered at about half-tide. In this mud Corophium volutator forms the dominant species of the animal community. In bright sunny weather Corophium could be found crawling freely over the surface, and could easily be collected in large numbers. It soon became apparent that only the larger individuals were being captured in this way, and accordingly an attempt was made to devise a simple method of collecting fairly large numbers which, if not giving a really true index of the density of population, at any rate seemed to ensure a fair proportion of the smaller individuals being caught. The procedure was as follows:-

The mud over an area of $1 \mathrm{sq}$. metre was scooped up to a depth of about 5 in. (about the maximum depth of Corophium burrows) and passed through a wire sieve of $1 \mathrm{sq}$. mm. mesh. The Corophium left amongst the larger detritus were then picked out with forceps. Even so it was found that comparatively few of the smaller free-living young were caught, but it was impossible to use a smaller mesh, as the work was thereby rendered so slow that even $1 \mathrm{sq}$. $\mathrm{m}$. of mud could not be worked in one intertidal period. Accordingly 500 c.c. samples of mud were taken and sieved out at leisure in the laboratory, thus affording a rough indication of the numbers of young present.

In attempting further to elucidate the nature of the life-cycle, living Corophium, caught in October, were successfully kept in an aerated tank, supplied with mud, sea-water, and a circulating apparatus in the laboratory at Leeds for a considerable period, but the animal does not seem to breed in winter, not, at any rate, in the North, and unfortunately during the great frost of February, 1929, the heating was kept on day and night and the animals incontinently perished.

I was therefore forced to rely largely upon measurement investigations of the type evolved by Blegvad (3) in his great work on the Biology of Gammarus locusta. As I was only able to make four quantitative collections from Whitby : in July, October, and December, 1928, and March, 1929, these measurements can hardly be considered really critical. A further sample, very kindly sent to me by Mr. George Duke of Robin Hood's Bay on April 13th, helped to strengthen the argument considerably, and in conjunction with a careful examination of each specimen as it was measured, a life-cycle of a type essentially similar to that postulated 
by Blegvad (loc. cit.) for a number of littoral Amphipoda, seemed to be disclosed. I therefore considered it worth while tabulating the results, in the hope of vindicating them by a more thorough investigation in the future.

The method of measuring employed was the same as that described by Blegvad: the animals were extended on a millimetre scale under a dissecting microscope and the length taken from telson to rostrum.

To gain an accurate idea of the nature of the substratum in which Corophium volutator lives, samples of mud from the different localities worked were graded and analysed for organic content by the method used by Allen (1) for classifying bottom-deposits.

The salinity range of the water in the natural habitat of this species must be considerable, and constantly varying. Some estimations by silver nitrate titration were made, however, with a view to comparing the probable range in the different localities. To determine the change in salinity which the animals could actually endure, small numbers were isolated under different conditions, with a small amount of mud from their natural habitat.

To ascertain the nature of the food, small numbers of living Corophium were kept under various conditions in finger bowls and small dishes, aerated with a pipette at definite intervals. Strips of Ulva, Enteromorpha, and decaying deciduous leaves were tried as food, but without success, as it appears that the animals feed on smaller particles of organic detritus. When mud from the natural habitat was supplied, small winter-caught Corophium could be kept almost indefinitely under these: conditions.

The actual feeding process was observed partly by fixing the animal on its back in a capsule of sea-water with plasticine, and using a dissecting. microscope, and partly by enclosing living individuals against the side of a rectangular slide-trough and observing them with binocular mounted horizontally.

To observe swimming currents, etc., suspensions of carmine and starch stained with iodine were employed.

In examining the structure of the appendages various methods were tried. Staining with acetic-alum-carmine, Bethe's old stain for chitin, and picro-nigrosin, showed the musculature and general features very beautifully, but the two last-named are difficult to control. Finally, it was found that the arrangement of spines and setæ could best be made out by comparing glycerine mounts of $(a)$ fresh material ; $(b)$ material fixed in formalin-sea-water; and $(c)$ similar material subsequently treated with alcoholic potash, a method which Hansen has recommended.

The arrangement of the mouth-parts was in part made out by dissection, and also by cutting thick sections of material embedded in 
clove-oil-celloidin. This modification of Cannon's method was evolved by Mr. Dennell.

\section{GENERAL BIOLOGY.}

\section{Habitat, Substratum and Salinity.}

Though often occurring in great numbers, $C$. volutator has an exceedingly localised distribution. The unfortunate naturalist who is in need of specimens, and simply goes to the nearest estuarine mud-flat to find them, is likely to have a day's arduous search for nothing. With foul black mud, or Zostera, they will have nothing to do, but are to be found in certain areas of fairly soft greyish mud, when the other conditions are suitable.

A good description of a typical habitat for $C$. volutator has been given by Delage (8) in his work on the circulation of the Edriophthalma; he says, "Corophium is found at Roscoff, in the mud of the harbour. They are not really very abundant except in an easily defined zone a little below the level of high-water neaps. At places where the mud is rendered black by abundance of decaying organic detritus, one never finds them." Stephensen (20) quotes Th. Mortensen to the effect that in company with the Spionid Pygospio elegans Claparède, Corophium is very numerous. in certain areas of sandy mud in some of the Danish Fjords where the salinity is fairly low (ca.6-16\% $)$. Finally, Gurney (10) has described Corophium volutator living in colonies of the hydroid Cordylophora, when ascending far up the East Anglian rivers into regions where the salinity is very slight.

Descriptions such as sandy mud, and mud not blackened by decaying organic matter, do not give sufficient information as to composition, and Dr. Orton suggested that it would be useful to give an accurate description of the mud which C. volutator normally inhabits. This I have attempted to do by the methods Allen (1) employed for grading bottom deposits.

The mud was passed through sieves with perforated zinc bottoms, the perforations being $5,2.5,1$, and $0.5 \mathrm{~mm}$. in diameter.

The portions retained by each sieve were dried on a filter paper, and later by gentle heat. Most of the mud passed through these sieves. Of the remainder, that which settled in the washing water in one minute was collected and dried, being equivalent to the " fine-sand " grade, and the residue in the water was left for 24 hours to settle, representing Allen's. "Silt." The various fractions were carefully dried and weighed, and their percentage of the total sample calculated. Only in Whitby mud were the portions retained by the sieves an appreciable fraction of the total dry weight, and there they formed barely $9 \%$. Accordingly in describing the different muds I have termed them collectively the " coarse grades," fine sand, and silt being spoken of as "fine grades." 
Having obtained the dry weight of the various grades, the organic content was found by loss in weight on bunsen ignition (R. H. Worth, in 1). I have not yet been able to carry out investigations of the carbonate content, for which blow-pipe ignition was needed. This is unfortunate as the $\mathrm{pH}$ of the muds is definitely on the alkaline side, $c a .8 \cdot 2$, which is surprising in view of the high organic content. In the course of this part of the work, it became very evident that an investigation of the physical factors of muddy foreshores, as influencing the organisms living on them, of the type recently worked out by J. R. Bruce (Journ. Mar. Biol. Assoc., $\mathrm{XV}$, No. 2) for sandy beaches, would prove a very interesting and probably valuable study in itself.

Samples of mud from three different localities worked, Whitby, Salcombe and Calstock, have been analysed by the above methods, and the results, together with rough values for the salinity and frequency of Corophium in the different localities, are given in Tables I, II, and III.

Corophium is most abundant at Whitby (Table I), and is, moreover, the dominant species of the animal community of the mud there. In this mud there is a certain amount of shelly gravel, small stones and coarse sand, to the extent of nearly $9 \%$ of the dry weight, though some of this is due to large organic, mainly deciduous detritus, of the remaining $91 \%, 56 \%$ represents fine sand and $35 \%$ silt. The total organic content is $6 \cdot 32 \%$ by weight. The coarse grades contain relatively twice as much organic matter as the fine grades. The salinity range appeared to be $21 \cdot 8-35^{\circ} \%$.

At Salcombe (Table II) Corophium is very scarce and this is probably due to the fact that the mud dries off almost completely at low tide, which is never the case where Corophium is plentiful. A titration gave $35 \cdot 2 \%$ 。 at half-flood (Corophium level in this Estuary). The mud on the whole is very similar to the Calstock sample, though the total organic content is not so high - only $7 \cdot 08 \%$ by weight. The whole character of the mud is finer than the Whitby sample, as silt exceeds fine sand here by $12 \%$.

At Calstock (Table III) the mud is finer still, and the organic content is higher, $10 \cdot 41 \%$ by weight. It is therefore improbable that the texture of the mud is responsible for the scarcity of Corophium at Salcombe, as at Calstock it is fairly plentiful, $c a .40$ individuals per sq. m. The cause of the disparity between the populations of these two localities is to be sought for in the almost complete drying-off of the mud at Salcombe. In the case of the relative frequency at Whitby (ca. 150 per m. sq.) and Calstock, I have no doubt that the difference is due to the texture and general character of the mud of the two localities. The coarser Whitby mud would allow of more rapid diffusion of oxygenated water by capillarity between its particles, and the Calstock mud, with its high organic content, is verging on the blackened condition in which, as Delage long ago pointed out, one never finds Corophium. It is true that the salinity at Calstock 
must be appreciably lower than at Whitby. At Calstock a titration of flood-time water indicated $22.8 \%$ as the upper limit of the range. But Corophium from any of the three localities would withstand great dilution under laboratory conditions, and it seems probable that only the extreme limit of tidal influence would prove to be the limit of their riverward extension in nature. A factor which must also be taken into account is the rate of evaporation during the intertidal period. Some of Bruce's results

\section{TABLE I.}

Analyses of Mud Inhabited by Corophidm volutator.

Wнгтву.—W. side Harbour, opposite L. \& N.E.R. Goods Yard.

$\begin{array}{cccc}\text { Grade. } & \begin{array}{c}\text { Dry wt. \% of } \\ \text { total sample. } \\ \text { grm. }\end{array} & \begin{array}{c}\text { Org. cont. } \\ \text { \% by wt. of } \\ \text { total sample. } \\ \text { grm. }\end{array} & \begin{array}{c}\text { Org. cont. } \\ \% \text { of total } \\ \text { organic wt. } \\ \text { grm. }\end{array} \\ 2.5 \mathrm{~mm} . \text { sieve } & 5 \cdot 39 & 0 \cdot 49 & 7 \cdot 75 \\ 1 \mathrm{~mm} . \text { ", } & 0 \cdot 97 & 0 \cdot 19 & 3 \cdot 01 \\ 0.5 \mathrm{~mm} . & 1 \cdot 34 & 0 \cdot 14 & 2 \cdot 12 \\ 1 \mathrm{~min} . & 1 \cdot 11 & 0 \cdot 07 & 1 \cdot 12 \\ 4 \mathrm{hrs} . & 56 \cdot 17 & 1 \cdot 94 & 30 \cdot 62 \\ & 35 \cdot 04 & 3 \cdot 49 & 55 \cdot 38\end{array}$

Total organic content $\%$ by wt. $6 \cdot 32$

Coarse grades, gravel, shell fragments, large vegetable detritus, $8 \cdot 788 \%$.

Fine sand and silt, $91 \cdot 312 \%$.

Organic content of coarse grades, $10 \cdot 13 \%$ by wt.

Organic content of fine grades, $5 \cdot 08 \%$ by wt.

Corophium dominant, over 150 per sq. m., few small.

Nereis diversicolor etc., salinity $21 \cdot 8-35(?) \% 0^{\circ}$

\section{TABLE II.}

Salcombe. Mud-flat Between Ditchend and Southpool Lake.

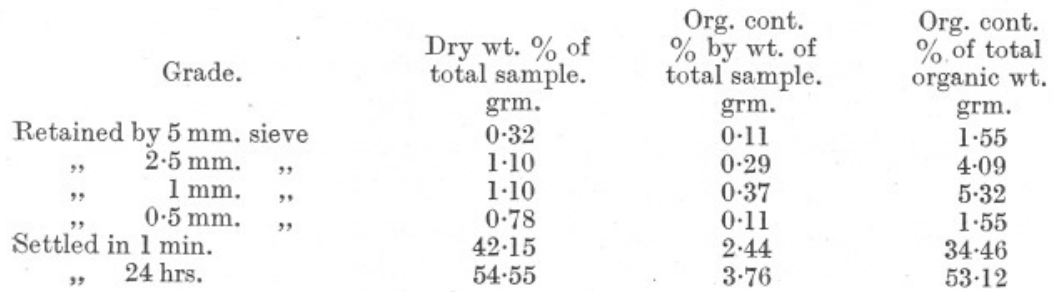

Total organic content $\%$ by wt., $7 \cdot 08$

Coarse grades (mainly shell fragments and vegetable detritus), $3 \cdot 40 \%$.

Fine sand and silt, $96 \cdot 60 \%$ by wt.

Organic content \% by wt. of coarse grades, $25 \cdot 88$.

Organic content $\%$ by wt. of fine grades, $6 \cdot 35$.

Corophium scarce, less than 1 per sq. m. Polychata (Melinna adriatica and Nereids) apparently dominant.

Salinity ebb-tide water $35 \cdot 2 \%$-conclude no dilution. 
TABLE III.

Calstock. Cornish Bank of the R. Tamar, half a mile below Village.

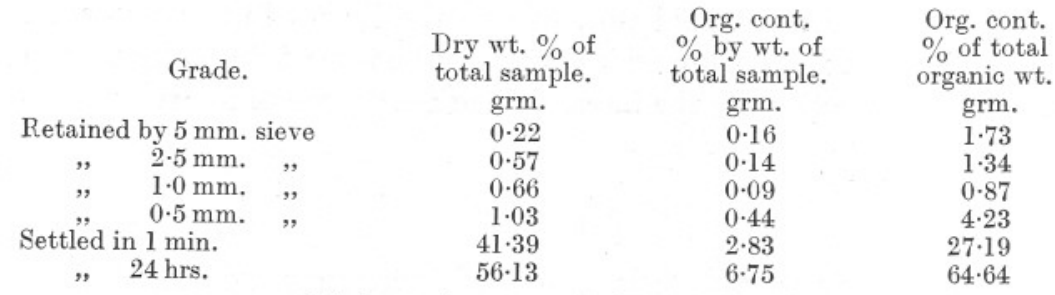

Total organic content \% by wt., $10 \cdot 41$

Coarse grades (vegetable detritus and gravel), $2 \cdot 48 \%$ by wt.

Fine sand and silt, $97 \cdot 52 \%$ by wt.

Organic content $\%$ by wt. of coarse grades, $33 \cdot 46$.

Organic content \% by wt. of fine grades, $9 \cdot 82$.

Corophium fairly plentiful, ca. 40 per sq. m. Nereis diversicolor (large) dominant.

Salinity range must be great, ca. $0 \cdot 8-16^{\circ} \%$ opposite Calstock itself (Percival, Jour. Mar. Biol. Assoc., Vol. XVI, 1929) on titration of flood-tide water gave $22.8 \%$.

indicate that in the coarser mud evaporation would be less rapid. As. before stated, Corophium is most plentiful where small puddles cover most. of the mud at low water, and where the mud is relatively coarse. The most productive locality I have yet found for Corophium is in a certain tidal creek in the Salicornia marsh at Blakeney Point, Norfolk. Here the mud is very coarse, the salinity never less than $34 \%$ and Corophium reaches a density of $c a .1000$ per $\mathrm{m}$. sq. Here also the organic content is very low $(0.8 \%$ by weight). The inference is that the nature of the substratum, and not the salinity of the water, is the chief factor defining the habitat of this species of Corophium.

In this connection it is interesting to compare the remarks of Ussing (22) in a brief account of the biology of Corophium Bonelli M. Edw. in Mariagerfjord, E. Denmark. He found this animal to be the dominant species of a definite Epifauna ("Paa-fauna ") on the Mytilus clumps, and that it attains its optimum opposite Aamölle where the salinity is $14-15^{\circ} \%$ " just like its companion C. grossipes (=C. volutator) in Randers Fjord." From the above I can only conclude that the substratum was more suited to Corophium than that found higher up the estuaries I have worked. Only once I have found Corophium really abundant in a region of really low salinity -in the mouth of a small river in N. Norfolk connecting by faulty sluice-gates with a tidal creek, known locally as "Stukey Freshes." Here in July Corophium was as plentiful as at Whitby, though the salinity was only $0 \cdot 7-3 \cdot 6 \%$. The mud was of about the same consistency as at Whitby, and organic content low. In September there was a heavy 
accumulation of vegetable detritus, and the stream had to be cleared, but not before Corophium had rapidly diminished in numbers.

In addition to those I have worked myself, I have found records of C. volutator from the following British localities:-East Norfolk rivers, ascending to regions of very slight salinity living amongst Cordylophora (Gurney) ; very abundant in the Dee estuary (Spence Bate) ; Exmouth (Allen and Todd); tide pools near high water, Lytham-St. Anne's, Ribble estuary (Prof. Garstang).

An idea of the extent of its geographical range may be gathered from the following scattered references : in Christiana Fjord at Moss, G. O. Sars ; at Hangesand on the W. coast of Norway, Boeck; Danish coasts, Stephensen; Bohnslaa, Bruzelius; Baltic, Lindstrom; Kattegat, Meinert; Dutch coast, Hoek ; coasts of France, Roscoff, Caen, Bernieressur-Mer, etc., Mercier and others ; Adriatic, Meller; besides the various British localities.

G. O. Sars (15) dredged C. volutator in 2-5 fathoms of water in Christiana Fjord, whereas round our coasts it is always found in the intertidal zone. This is possibly an example of the general fact that species with a wide geographical distribution tend to be found in deeper water towards the polar limit of their range.

As regards the actual change in salinity which $C$. volutator can endure, it was found that starting with 40 c.c. of sea-water and adding 15 c.c. distilled water daily two Salcombe caught males showed no signs of inconvenience at the end of three weeks. In another experiment specimens from Salcombe were put straight into fresh water and specimens from Calstock straight into laboratory tank water $\left(c a .36^{\circ} \%\right.$ ). The experiment was set up on April 13th and had to be discontinued on the 29th. Almost all the individuals (two females and one male were used in each experiment) were still flourishing, but such young as were hatched apparently died at the first moult, and one of the Calstock females died after the eggs had hatched. If the salinity were changed gradually therefore, it seems reasonable to suppose that Corophium could be kept and bred in fresh water, and possibly even in hypertonic sea-water.

\section{Burrowing and Locomotion.}

C. volutator normally burrows vertically into the mud to a depth of not more than five inches. Frequently the burrows are U-shaped, having two openings. When kept in a dish with a shallow layer of mud, shallow burrows, perforce nearly horizontal, are formed. If the mud is insufficient even for this, they agglutinate it together in clumsy tubes, reminiscent of the more workmanlike structures of the regular tube-building species, C. crassicorne, with the aid of the secretion from the glands of the second 
pereiopods, which is normally used merely to keep the walls of the burrows intact.

In burrowing, the large pediform second antennæ are first brought into play, and when these are immersed the gnathopods, and more particularly the first and second pairs of pereiopods, continue to enlarge the hole and haul the animal head-first into it, purchase being obtained by the elongated specialised fifth pereiopods. Additional drive is given by the continual beating of the abdominal pleopods and the bending of the abdomen under the body so that the uropod spines become embedded and propel the animal forward when the abdomen is straightened again. When crawling freely in the film of water on the surface of the mud $C$. volutator may progress slowly by scrambling action of the thoracic appendages and the beating of the pleopods, the first two pairs of pereiopods doing most of the work. A much more common method of progression, and one which is always used if the mud has dried oft completely, might well be described as "looping." The second antennæ are lifted, thrust forward, and the first joint hooked into the mud. The animal hauls itself up to them like a ship kedging off a shoal, what time the abdomen is flexed ventrally so that when the animal straightens out for the next heave with the antennæ, it is thrust forward a further half of its length by the straightening of the abdomen. This mode of locomotion gives an effect very similar to that of a looper caterpillar, and the animal can progress quite fast by it. The structures concerned obviously lend themselves very efficiently to the process, the uropods with their short strong spines forming an ideal fulcrum.

When swimming clear of the bottom, the animal nearly always lies on its back, though capable of performing complicated evolutions on occasions, to which its specific name is possibly due. The two great second antennæ are laid back like the arms of a man about to dive, so serving as an admirable cut-water. All the other limbs are held stiff, with the exception, of course, of the pleopods. These beat rhythmically, but exactly out of phase with each other, i.e. with a metachronial rhythm. The basal joints of the fourth and fifth pereiopods are provided with a dense fringe of plumose setæ, which apparently helps to confine the current produced by the pleopod and direct it backwards, so propelling the animal forward. This mode of progression might be aptly compared to that of the early stern-wheel paddle-steamers.

\section{Relations with Other Animals.}

In the section on feeding habits, it is shown that $C$. volutator feeds mainly in vegetable detritus, and is not actively carnivorous preying upon small worms and gasteropods, as was formerly supposed.

In the Whitby mud it was the dominant species in the animal community. In addition to Corophium I found fair numbers of small Nereis 
diversicolor and the small gasteropod Paludestrina stagnalis. Both these forms, in muds of a slightly different character, where Corophium is. absent, may be present in countless thousands. In the Whitby mud were also a few small Lamellibranchs, probably Tellina balthica. Besides these, in the runnels there were a few small specimens of Crangon vulgaris, and in March I found some berried individuals of Hippolyte varians. Small shore crabs were occasionally present, also flounders, which come up. on to the flats when the tide is up to feed on Corophium, and sometimes. get stranded in small runnels. In the stomach of one small flounder I found 32 Corophium, and no doubt other fish take them on occasions. C. salmonis, one of the two large species described by Bradley (5) from the Pacific coast of North America, is found in large numbers in some of the salmon there.

At Salcombe the mud, though stiffer, was also stickier, and Corophium was scarce. Nereis and Melinna adriatica, which builds vertical tubes. coming just above the surface of the mud, appeared to be dominant.

The Calstock mud was softer and darker than that at Whitby. Large Nereis diversicolor were dominant, and Corophium was fairly plentiful. I saw no signs of any other animals.

In the two localities worked at Blakeney Point, the salt-water " Yankee Creek" and the brackish "Stukey Freshes," Corophium was in both cases dominant though infinitely more abundant in the former. In "Yankee Creek" there were besides Corophium a large number of small Nereis diversicolor, but these were outnumbered five to one. A few Tellina fragilis, Carcinus, and Crangon vulgaris were also present. At "Stukey Freshes " other animals inhabiting the mud were Nereis diversicolor and the Isopods Cyathura carinata and Spharoma rugicauda.

Besides fish, Corophium is preyed upon by wading birds and gulls. I have an original sketch by Mr. A. H. Patterson of Yarmouth of a wader with a Corophium struggling in its bill.

I have not as yet noted any parasites, apart from the fact that several of the Whitby Corophium had small individuals of Mytilus growing upon them. Presumably the spat, falling upon soft and unsuitable ground, finds in Corophium the best apology available for a hard substratum.

\section{Feeding Habits.}

Bate and Westwood (2) state that $C$. volutator attacks Annelids and Molluses, the only other animals commonly occurring in the same mud. They give a "charming vignette" of the animal engaged in a mighty struggle with a Nereid, and state that combined assaults of such a nature are more common. However, they admit in their introduction that it is doubtful whether Corophium really does feed thus, and also admit the 
improbability of the supposed migration of Corophium to deeper water in winter. Their accounts of these two phenomena are based on a letter from an early and obscure French naturalist to Latreille.

It seemed much more probable that like the majority of littoral Amphipoda, Corophium would feed on the organic detritus, mainly vegetable, present in its natural habitat. Before any attempt to study the actual feeding process was made, an experiment was set up with a view to determining this.

Small numbers of winter-caught Corophium were isolated in equal volumes of sea-water under various conditions. In the control, only the freshly filtered sea-water was present ; in another bowl mud was placed in which the organic matter had been destroyed by ignition; another
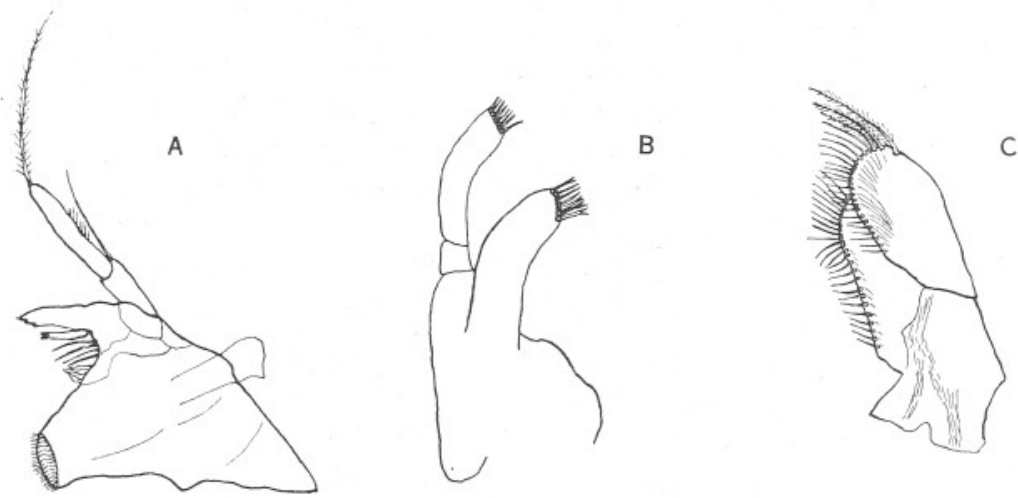

Fra. 1.-A, mandible; B, 1st maxilla; C, 2nd maxilla. $\times 12$.

contained mud from which all large particles had been removed by passage through a $0.5 \mathrm{~mm}$. sieve ; and in the last was mud direct from the natural habitat. By the end of a fortnight, the animals in the control experiment and with the sterilised mud were dead. Those with the sieved mud lived nearly 6 weeks, and those with natural mud were still flourishing nearly 7 weeks after the experiment had been set up, and made no attempt to molest the small molluses present. It was thus obvious that $C$. volutator feeds on the organic detritus in the mud, together with the attendant micro-organisms, and investigations of the feeding mechanism were begun.

So far from being an active carnivorous feeder, then, Corophium volutator seems to feed almost entirely by selecting particles from the mud in which it lives. For this purpose the mouth-parts and gnathopods, particularly the first pair, are very well adapted. It would seem to be a true selective deposit feeder in Hunt's sense, though when in its burrow the current produced by the beating of the pleopod brings small particles 
in suspension over the setæ fringing the gnathopod, so that in addition there is a filter-feeding mechanism. This last, however, is not the most important method of feeding, as nearly all the individuals examined had particles in the foregut, and adhering to the mouth-parts, of a size that are not moved by the current produced by the pleopods, even when this
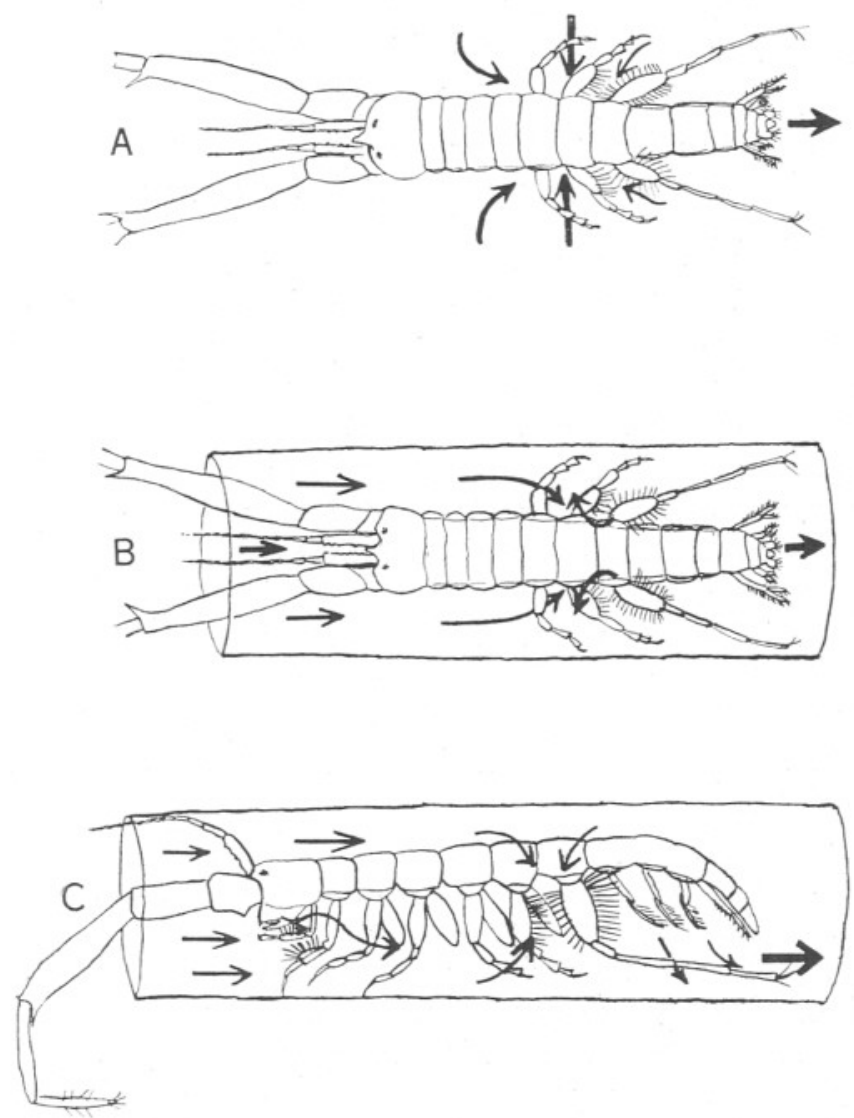

FIG. 2.-Diagrams showing the currents formed by Corophium. $\mathrm{A}$, when crawling freely over the bottom; B and C, when enclosed in a tube.

current is concentrated by the walls of a tube. This can be proved by observing Corophium in a glass tube in a dish of water and adding mud from the natural habitat. Only the finest particles are carried in by the current. The confining influence of a tube is necessary for the filterfeeding mechanism to be operative at all. Otherwise the strong inflowing current is entirely lateral, as indicated in Figure 2. 
By observation with a binocular microscope, of vigorous fresh-caught Corophium introduced into a glass tube as described above, the course of the currents, and the method of passing the particles caught to the inner mouth-parts can be followed (Fig. 2).

Before the feeding mechanism can be clearly explained it is necessary to give some account of the topography of the mouth-parts.

The labrum descends vertically from the extreme end of the head, and is provided with a row of small inwardly directed close set teeth near its inferior margin. On either side of the mouth-opening and immediately behind the labrum lie the mandibles. The incisor processes meet ventrally in close juxtaposition to the free edge of the labrum. The large molar processes are visible in sections at this level, lying deeper, i.e. nearer the mouth-opening proper, but their broad grinding surfaces are much wider than the incisors, and extend some distance further back in the plane of the long axis of the animal. The spinose ends of the plates of the first maxillæ overlap this backward extension of the mandibles. Overlying these ventrally come the setose plates of the second maxillæ, and outside these again are the maxillipeds, with the palps reaching as far forward as the labrum, to complete a sort of basket under the head of the animal opening forwards and inwards at the mouth (Figs. 1 and 4).

The mouth-opening itself is somewhat indefinite, lying buried beneath the molar processes of the mandibles. The paragnaths are scarcely developed at all, just two slightly raised blunt lobes with a fringe of fine short setæ, at the posterior end of the mouth-opening. Sections show the region of the mouth-opening and œsophagus to be richly supplied with glandular tissue.

When behaving as a selective deposit feeder, C. volutator crawls slowly about over the surface of the mud, or occasionally, on finding a patch rich in organic detritus, remains stationary while the feeding goes on. With the first gnathopods it scoops up and sifts small quantities of mud-when viewed laterally with the binocular the rain of rejected particles could clearly be seen. Larger fragments of algal detritus, etc., appeared to be conveyed to the incisor processes direct by the two terminal joints of the gnathopods. The smaller particles are retained in the fringe of the setæ on the fifth joint of the first gnathapods.

The larger food masses are not cut up by the incisor processes, which are manifestly unfitted for such a purpose, but are, as it were, tucked in between the molar processes by their action. The mandibles move laterally outwards and inwards as indicated in Figure $3, \mathrm{~A}$. The particles are thrust in between the molars largely by the action of the laciniæ, and the spines that lie between them and the molars.

A considerable amount of secretion from the glands in the œsophageal wall is poured out into the cavity formed by the mouth-parts. Pear- 
shaped masses of smaller food particles agglutinated together, are frequently found on the spines of the mandibles and first maxillæ.

When acting as a suspension feeder, the particles are drawn into the net formed by the fringing setæ of both first and second gnathopods, by the currents set up in the burrow (or glass tube) by the beating of the pleopods. The particles are combed out of the fringe of the second gnathopods on to the first gnathopod fringe, and their further course to the mouth is the same as that taken by the smaller particles obtained when deposit-feeding.

The transference of the smaller food particles from the setæ fringing the fifth joint of the first gnathopods to the mouth is not easy to follow, owing to the small size of the mouth-parts and the rapidity of their movements. Repeated observations of the animal fastened down upon its back with plasticine enabled the main part of the process to be made out.

The gnathopods are moved up and down against each other in the manner indicated in Figure 3, B, until the sifting of the useless particles appears to be completed to the animal's satisfaction. Even so, a large part of the gut contents can only be described as mud. One of the gnathopods is then inclined inwards so that by the rapid champing action of the maxillipeds the food particles are combed out of the setæ fringe on the gnathopod. The movement of the maxillipeds appears to be purely lateral, and the fringe of fine spines on the outer plate, together with those on the palp, appear to be the chief agents in collecting the food particles. The spines on the outer plate are so set in a sort of ball-and-socket joint that when the maxillipeds are closed, the joint admits of their being projected forwards at an angle, but not back. When the maxillipeds are opened laterally these spines are pointing inwards at right angles to the margin of the plate (Fig. 3, C), but when they close the spines bend forwards so that the food particles combed from the gnathopod fringe are thrust forward until they come within the radius of action of the incisor processes and first maxillæ (Fig. 3, C 2). It is possible that the armature of the second maxillæ functions in the same way as that of the maxillipeds, but the organs in question do not seem to play any important part in the feeding process.

The ends of the outer plates and palps of the first maxillæ move downwards and outwards, then upwards and inwards, and with the help of the secretion from the salivary glands, appear to do the bulk of the work of passing food particles on from the maxillipeds to the mandibles. Some of the larger particles, however, seemed to be passed direct to the inner side of the incisor processes by the palps of the maxillipeds.

Most of the food seems to be ground up into a pasty mass by the molar processes, but some particles, particularly fragments of algal filaments, appear to reach the fore-gut without undergoing this trituration.

The actual process of swallowing is not at all clear, but it seems probable 
that suction set up by contraction of the diagonal muscles of the foregut wall may be the chief factor. The dilated horizontal part of the foregut or crop contains an exceedingly complicated arrangement of spines,

A 1
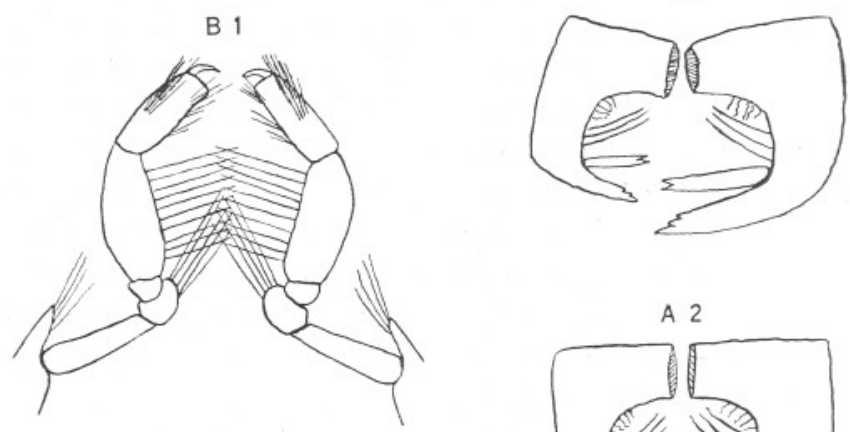

B 2
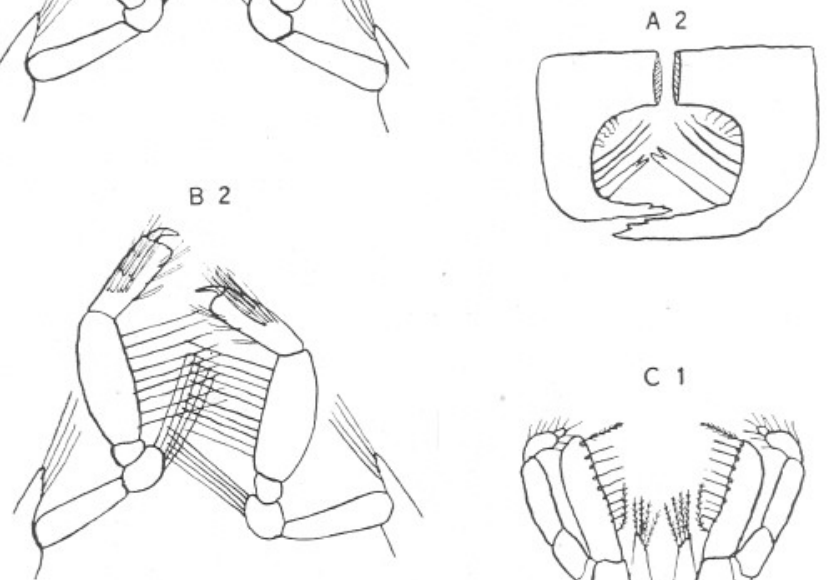

B 3

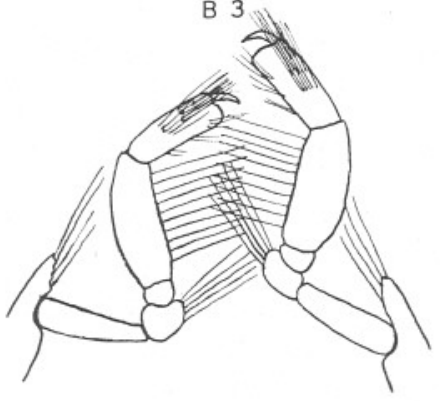

C 1

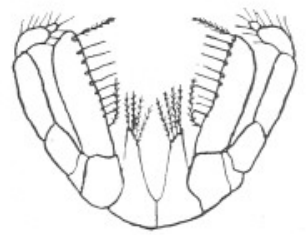

C 2

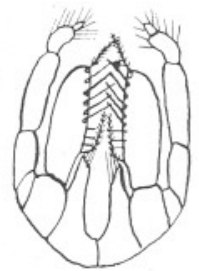

FIG. 3,-Diagrams illustrating the feeding mechanism. A, action of the mandibles; B, sifting action of the first gnathopods; $\mathrm{C}$, action of the spines on the maxillipeds.

denticles and setæ, by means of which the undigested food is still further triturated. Obviously this can only take place by the action of the muscles in the wall of the crop, and it seems quite probable that this same action 
sets up a suction by means of which further food particles are drawn up the œsophagus.

The œsophagus ascends almost vertically into the wide triturating stomach or crop (also sometimes termed the proventriculus) which projects anteriorly in front of the level of the mouth-opening. The forward end of the crop contains a circular ring of chitin set with strong backwardly directed triangular teeth, the "triturationsapparat" of German authors, at the level of the œsophageal opening. Just behind this is a ring set with numerous fine setæ, also directed backwards.

Further back a large ridge rises from the floor of the fore-gut and almost divides it longitudinally into two halves. This ridge is set with a fur of very fine short setæ round the crest, and on the sides with parallel rows

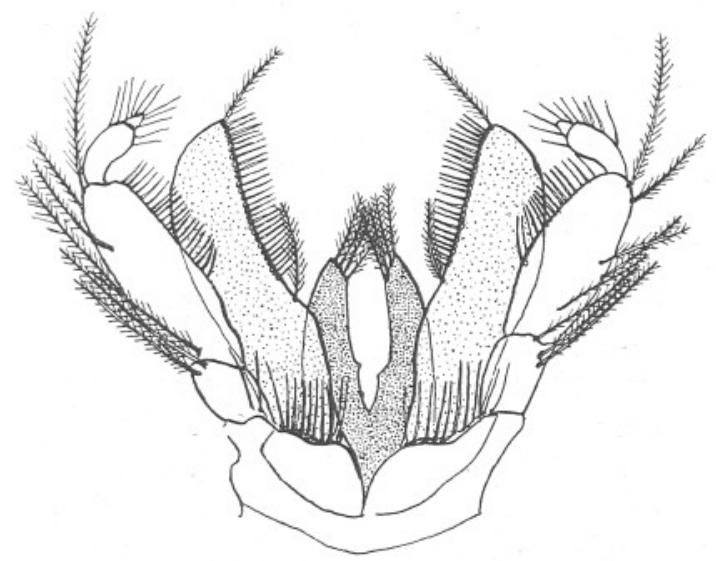

FIG. 4.-Maxillipeds, as seen from below. $\times 120$.

of low chitinous denticles. At the extreme postero-dorsal end, the ridge also bears a tuft of longer setæ directed backwards. The armature of the ridge in general closely resembles that of the molar processes of the mandibles. On either side, where the lateral walls of the fore-gut join the floor, a low ridge is to be found directed obliquely inwards, crowned with fine short setæ. The whole apparatus will obviously furnish a very efficient triturating apparatus when the gut walls are violently contracted. These walls contain many strong diagonally interlacing muscle-bands, giving an appearance reminiscent of the network of a balloon. Behind the proventriculus the gut narrows abruptly, but the fore-gut is prolonged as a sort of funnel for some distance into the mid-gut lumen.

Little could be seen of the actual mastication of food within the proventriculus in the adult, for obvious reasons, but in young transparent individuals a violent periodic lateral contraction, followed by peristaltic 
movement of food down the mid-gut, could clearly be seen. These spasmodic contractions were always followed by the appearance of a fresh supply of food particles in the proventriculus. Hence, I incline to the view that the swallowing process is to be attributed to the sucking action. of the crop.

\section{Life-Cycle and Breeding Habits.}

\section{Results of Measurement Investigations.}

Samples from $1 \mathrm{sq}$. m. of the Whitby mud were taken at the four seasons of the year, by the methods described earlier in this paper. All the measurements were made by Blegvad's method-taking the length in millimetres from telson to rostrum: and in the case of the females, the condition of the oostegites, and eggs or young if present, was carefully examined in each individual as it was measured.

The smallest individuals in which the sexes could be distinguished with any degree of certainty without dissecting off the antennæ were about $3 \mathrm{~mm}$. long. In some of these, though the oostegites were not developed, the two spines on the inferior margin of the first joint of the first antennæ, so characteristic of the females, could clearly be seen. This is a most constant secondary sexual character in all the material I have examined. All specimens below this size are lumped together as "young" in the following tables. As many of them doubtless escaped the mesh their numbers have little significance, apart from their relative frequency at midsummer, when the animals are breeding, and through autumn and winter when breeding has ceased but development is very slow: and scarcity in the spring, when the last hatched broods of the previous summer are just reaching maturity, and the animals are about to begin breeding again.

Table IV deals with the sample of Corophium volutator obtained from 1 sq. m. of Whitby mud on July 20th, 1928. In addition to the tabulated specimens, this sample contained 53 young under $3 \mathrm{~mm}$. in length. It will be seen that immature specimens of both sexes are almost entirely lacking, from which it would seem that the first brood of the year had just reached maturity. From the measurements given it also appears that maturity is reached at a length of $c a .5 .5 \mathrm{~mm}$. in the case of the summer stock. In the great majority of the larger females the eggs were in the same advanced stage of development. I take it that this shows the free-living young of the July sample to be representative of the second or third brood of the year, as information gathered during the following April points to three weeks as the maximum period of incubation, and breeding commenced in the second week of that month.

From the figures given in Table IV it will be seen that quite a large proportion of the $7 \mathrm{~mm}$. females were without eggs, but had the brood 
pouch fully formed. It would seem that these represent the last of the winter stock to reach maturity, and they had probably only produced one brood when taken. The validity of this supposition is greatly enhanced when the March measurements (shortly to be described) are taken into account.

\section{TABLE IV.}

\section{Results of Measurement Investigations.}

Whitby sample. July 20th, 1928,

Total number of individuals examined, 196, of which 55 were young under $3 \mathrm{~mm}$. in length, 73 females ranging from 5-9.5 mm., 35 males varying between $6-9.5 \mathrm{~mm}$. in length, and 33 females not so fully examined of length $5-8 \mathrm{~mm}$. The first series shows the information gathered from the females examined in detail.

\begin{tabular}{|c|c|c|c|c|c|c|c|}
\hline $\begin{array}{l}\text { Length mm. } \\
\text { telson to } \\
\text { rostrum. }\end{array}$ & $\begin{array}{l}\text { No. of } \\
\text { individuals. }\end{array}$ & $\begin{array}{c}\text { No. } \\
\text { with eggs. }\end{array}$ & $\begin{array}{l}\text { No: without } \\
\text { eggs, but } \\
\text { brood pouch } \\
\text { present. }\end{array}$ & $\begin{array}{l}\text { No. having } \\
\text { eggs with } \\
\text { curled } \\
\text { embryos. }\end{array}$ & $\begin{array}{c}\text { Max. no. } \\
\text { of eggs } \\
\text { per brood. }\end{array}$ & $\begin{array}{l}\text { Min. eggs } \\
\text { per brood. }\end{array}$ & $\begin{array}{c}\text { Average no. } \\
\text { of eggs } \\
\text { per brood. }\end{array}$ \\
\hline 5 & 1 & - & - & - & - & - & - \\
\hline $5 \cdot 5$ & 3 & 2 & - & 2 & 8 & 4 & 6 \\
\hline 6 & 3 & 2 & 1 & 2 & 12 & 9 & $10 \cdot 5$ \\
\hline $6 \cdot 5$ & 10 & 8 & 2 & 6 & 35 & 11 & 25 \\
\hline 7 & 22 & 13 & 9 & 12 & 39 & 24 & $28 \cdot 7$ \\
\hline $7 \cdot 5$ & 15 & 11 & 4 & 10 & 48 & 25 & 33 \\
\hline 8 & 13 & 11 & 2 & 11 & 45 & 21 & $34 \cdot 5$ \\
\hline $8 \cdot 5$ & 3 & 2 & 1 & 2 & 39 & 32 & $35 \cdot 5$ \\
\hline 9 & 1 & - & 1 & - & - & - & - \\
\hline $9 \cdot 5$ & 1 & - & 1 & - & - & - & - \\
\hline
\end{tabular}

Particulars from 33 more females, not so closely examined.

$\begin{array}{lrrr}5 & 2 & - & - \\ 5 \cdot 5 & 1 & - & - \\ 6 & 3 & 2 & 1 \\ 6 \cdot 5 & 4 & 4 & - \\ 7 & 14 & 10 & 4 \\ 7 \cdot 5 & 4 & 4 & - \\ 8 & 2 & 1 & 1\end{array}$

TABLE V.

Length in $\mathrm{mm}$.

$\begin{array}{lllrlllll}\text { telson to rostrum } & 6 & 6 \cdot 5 & 7 & 7 \cdot 5 & 8 & 8 \cdot 5 & 9 & 9 \cdot 5 \\ \text { No. of individuals } & 1 & 2 & 10 & 8 & 7 & 5 & - & 1\end{array}$

Table VI shows the measurements of the sample taken on October 10th, 1928. The scarcity of adults, particularly males, and larger immature stages, together with the increased proportion of free-living young was very marked. None of the larger females had eggs ; indeed, it was found that the hairs were missing from the oostegites, which showed notches where the hairs are present during the breeding season. This was borne out by examination of some forty individuals apart from those in the mature sample. My opinion is that the apparent scarcity of $C$. volutator during the autumn and winter months is not due to any migration into 
deeper water as was suggested by Bate and Westwood (2), but to two main factors: firstly, that the adults, in particular the males, are dying off rapidly; secondly, that small free-living young, which do not become mature until the following spring, are exceedingly numerous, but defy ordinary methods of capture.

\section{Table VI.}

\section{Results of Measurement Investigations.}

Size and frequency of the Whitby sample obtained on October 10th, 1928. N.B. A 500 c.c. sample put through a finer sieve yielded 33 young. The females were not breeding.

$\begin{array}{cccc}\text { Length in mm. } & \text { Nos. of } & \text { Nos. of } & \\ \text { telson to rostrum. } & \text { Females. } & \text { Males. } & \text { Young. } \\ \text { Under } 3 & - & - & 21 \\ 3 & 12 & - & - \\ 4 & 6 & - & - \\ 5 & 4 & - & \\ 6 & 3 & - & \\ 7 & 12 & 1 & \\ 8 & 1 & 1 & \end{array}$

The total number of individuals examined was 64 , of which 41 were females, 2 males and 21 young.

\section{Table VII.}

Measurements of a sample obtained at Whitby on December 29th, 1928. Only 60 individuals were found, of which 51 were females, mostly immature, 3 were males, and 6 young. A 500 c.c. sample put through a fine sieve again indicated that many young had escaped the larger mesh, as 14 young were found in it.

$\begin{array}{cccc}\text { Length in mm. } & \begin{array}{c}\text { Nos. of } \\ \text { Females. }\end{array} & \begin{array}{c}\text { Nos. of } \\ \text { Males. }\end{array} & \begin{array}{c}\text { Nos. of } \\ \text { Young. }\end{array} \\ \text { Under to rostrum. } & - & - & 6 \\ 3 & 12 & - & - \\ 4 & 18 & 1 & - \\ 5 & 7 & - & - \\ 6 & 6 & - & \\ 7 & 4 & 1 & \end{array}$

In order to prove that Corophium is not so scarce in October as the metre sample indicated, a sample of 500 c.c. of mud was put through a fine sieve in the laboratory, when 33 young were discovered. As this volume only represents about $1 / 20$ th of the metre sample, it will be seen that the scarcity of Corophium in the autumn is confined to the adults and larger immature stages. The occurrence of a fair number of individuals $7 \mathrm{~mm}$. long or over shows that the adults of the previous summer had not completely died off, as one would expect thus early in the " off-season."

In the sample obtained on December 29th, 1928, the number of adults was still smaller, and the number of free-living young in 500 c.c. of mud had decreased to 14 ; but the number of small immature stages was considerably greater, as shown in Table VII. No breeding animals were 
observed, though 21 large females apart from the sample were examined. Their oostegites were hairless, with notches where the hairs are found in the breeding season.

The last sample I have so far been able to take at Whitby was collected on March 28th, 1929 (Tables VIII and IX). The wintered females were obviously almost ready to breed, but though 107 in all were subjected to the closest scrutiny, not one was discovered actually breeding. Indeed, their oostegites were still hairless, even in the larger individuals, but were not notched as are those of the mature females of the previous summer which live on into the winter. All the latter seemed to have died off.

The following Tables VIII and IX show the results obtained from the metre sample taken at Whitby on March 28th, 1929. The males which are dealt with were more numerous than at any other time of the year. In all, this sample contained 184 specimens, of which 5 only were young under $3 \mathrm{~mm}$. long, 70 were males ranging from 4-8.5 mm. in length, and 107 females of length 3-8 mm., none of which were breeding. A 500 c.c. sample put through a fine sieve did not yield any young, but 20 immature specimens of both sexes, from 4-6 mm. in length.

\section{TABLE VIII.}

Length in $\mathrm{mm}$.

$\begin{array}{lllllllllll}\text { telson to rostrum } & 4 & 4 \cdot 5 & 5 & 5 \cdot 5 & 6 & 6 \cdot 5 & 7 & 7 \cdot 5 & 8 & 8 \cdot 5 \\ \text { Nos, of males } & 2 & 4 & 9 & 10 & 24 & 7 & 9 & 1 & 3 & 1\end{array}$

\section{TABLE IX.}

The females showed all stages of development of the oostegites, but in general, the larger the individuals the more advanced was this development, as shown below :-

$\begin{array}{ccccc}\begin{array}{c}\text { Length in mm. } \\ \text { telson to rostrum. }\end{array} & \begin{array}{c}\text { Nos. of } \\ \text { Females. }\end{array} & \begin{array}{c}\text { Nos. without } \\ \text { oostegites. }\end{array} & \begin{array}{c}\text { Oostegites } \\ \text { small or } \\ \text { vestigeal. }\end{array} & \begin{array}{c}\text { Oostegites well } \\ \text { developed but } \\ \text { hairless. }\end{array} \\ 3 & 10 & 10 & - & - \\ 3 \cdot 5 & 9 & 9 & - & - \\ 4 & 11 & 10 & 1 & - \\ 4 \cdot 5 & 14 & 3 & 11 & - \\ 5 & 15 & 3 & 11 & 6 \\ 5 \cdot 5 & 9 & - & - & 9 \\ 6 & 9 & - & - & 11 \\ 7 & 11 & - & - & 7 \\ 7 \cdot 5 & 7 & - & - & 1\end{array}$

The first vestiges of oostegites were observed on females $4.5 \mathrm{~mm}$. long. Larger females, of a size commonly found breeding in the summer, had well-developed oostegites, but these were hairless. It would seem, therefore, that not only is the growth of the winter stock slower than that of the summer stock, but that they also reach maturity at a greater size.

An additional small supply of Whitby material, captured on April 10th, 
and very kindly sent to me by Mr. George Duke of Robin Hood's Bay, showed that all the females were then developing hairy oostegites, and some had early eggs. The early eggs of $C$. volutator are easily distinguished from those at a later stage of development, as they are smaller, of a bright golden yellow colour, and held together by a viscid secretion.

On April 13th at Calstock, I found all the female Corophium breeding, mostly with eggs in this early stage.

Free-living young were scarce, so that it seems that even on the South coast they do not start breeding until April.

A few specimens of $C$. crassicorne dredged from Plymouth Sound about this time had advanced eggs, but it is quite possible that this species, like the closely similar $C$. Bonelli, breeds all the year round, as living below low water it will not have to cope with such great fluctuations of temperature as $C$. volutator.

Isolations of females with early eggs showed the probable time of incubation to be slightly over a fortnight, and this was borne out by a further sample from Whitby very kindly obtained for me by Mr. Wight on April 19th. This sample contained females nearly all of which had eggs at an advanced stage, whereas it was known that breeding had only just commenced at Whitby on April 10th. The first young were hatched on April 23rd, and by the 29th some were being extruded from the brood pouches. I have not yet been able to observe the mating of the $C$. volutator in captivity, so I am forced to rely on this indirect evidence, and can therefore only give an approximation of the incubation period at present.

The young remain at least five days in the brood pouch. They feed in it, for their guts can plainly be seen full of food, and at least the first moult must normally take place there.

The relative number of males was much higher in the spring sample than in the summer and, as before stated, adult males had become exceedingly scarce by October. From this it would seem that the earlier broods must contain many more males than those hatched in spring and early summer.

The conclusion arrived at from the above evidence concerning the lifecycle of Corophium volutator at Whitby were as follows :-

The breeding period lasts from April to September: several broods are hatched each year.

The last hatched broods mature slowly through the autumn and winter, and commence breeding in the following April. During autumn and winter the individuals which had reached maturity in the previous summer die off.

The species is thus annual or semi-annual. 


\section{The Young.}

The young of $C$. volutator are hatched with the full complement of adult appendages, as is the rule amongst the Gammaridea. The primary flagellum of the first antennæ consists of but three joints, instead of four, as Sexton (17) found in several species of Gammarus. The proportions of both pairs of antennæ to the rest of the body are very different from that of the adult. In the young the second antennæ are never more than onethird of the body-length, and the minute terminal flagellar joint of the adult is wanting. The armature of spines and setæ of several of the appendages is poorly developed or wanting in the young. Thus only a few of the large plumose setæ on the gnathopods are represented, and these appear as long spines of totally disproportionate size to the limb bearing them, and on which I have not been able to discern any accessory hairs. The fringe of plumose setæ on the basipodite of the 5th pereiopod is entirely wanting.

The form and proportions of the regions of the body in the young also differ from the adult. The general form is shorter and squatter, and the ventral flexure of the abdomen is more marked. The abdomen is also much larger in proportion to the rest of the body.

The epipodites are already present, as would be expected, for though remaining in the brood pouch for at least five days, during which time the first ecdysis takes place, the young are quite active, and feed within the pouch. This has also been observed in the young of Gammarus by Sexton (16). If dislodged they appear to be quite able to fend for themselves, but the first moult is a critical period, and in experiments in varying the salinity it was frequently found that under conditions which did not affect the adults adversely, all the young died at the first moult.

In some of the young taken from the brood pouch, probably after the first moult, a single large spine was present, directed obliquely forward from the basal joint of the fourth antennæ ventrally. Further study may show this to be the forerunner of the two spines characteristic of the immature and adult females. If this is so, Corophium volutator will be the only Amphipod so far studied in which the sexes can be distinguished at such an early stage.

\section{DISCUSSION AND SUMMARY}

The investigation of the habitat shows that the nature of the substratum is the chief factor influencing the distribution of Corophium volutator in this country. The accounts of Danish workers state that it reaches its optimum in regions of fairly low salinity. This is probably due to the fact that the mud is of suitable character higher up the vast estuarine areas of Denmark than it is in England. It has been shown that while Corophium 
can penetrate into regions of very slight salinity, it occurred in by far the greatest numbers at the "Yankee Creek" station, at Blakeney Point, Norfolk, where the mud is very coarse, the organic content low, and the salinity rarely falls below that of the North Sea outside. At "Stukey Freshes," also at Blakeney Point, Corophium was found in considerable abundance in July, although the salinity was very low $\left(3 \cdot 6^{\circ} \%\right)$. At this time the organic content of the mud was $6 \cdot 3 \%$ and the $\mathrm{pH} 8 \cdot 3$. In early September there was a vast accumulation of organic detritus at this station, and the $\mathrm{pH}$ was found to be $7 \cdot 7$. The numbers of Corophium present dwindled rapidly.

The conclusion reached is that while Corophium volutator is capable of withstanding great salinity change, its abundant occurrence is strictly limited by the chemical and physical character of the substratum.

The peculiar features of the structure of this Amphipod and its appendages, and the methods of feeding and locomotion to which these lead, are obviously of great advantage to an animal of its peculiar way of life.

C. volutator is a characteristic member of a definite type of animal community of which the other important forms are Nereid worms and the Gasteropod Paludestrina stagnalis. Where the conditions approach i.ts optimum, C. volutator forms the dominant species in this community, but it is also found in fair numbers in regions where Nereids become dominant. Danish writers also speak of it as occurring in immense numbers co-dominant with the Spionid Pygospio elegans.

In describing the Biology of the allied species, C. Bonelli, Ussing (22) mentions that this form also is a characterising species of a definite animal community. This is the well-marked Epifauna of the Mytilus clusters in certain Danish Fjords. Salinity would appear to be the chief factor influencing the distribution of this species, and where the conditions depart from its optimum, other members of the Epifauna become correspondingly more numerous.

As regards the feeding habits of $C$. volutator, the method of selective deposit feeding appeared to me much more important than suspension feeding. The method of dealing with the larger food masses recalls that described by Cannon and Manton ( $\boldsymbol{y}$ ) in Hemimysis lamornce, where large food masses are conveyed to the maxillules and incisor processes by the endites of the anterior thoracic limbs. In the Decapod, Leander serratus, large particles are dealt with by the chelipeds according to Borradaile (4), but the scooping up and sifting of the ooze by the gnathapods of Corophium finds a still closer parallel in the almost identical performance of the third maxillipeds of Hermit crabs (Orton, 13).

The suspension feeding when the animal is in its burrow, by means of the current set up by the pleopods, agrees almost exactly with the description given by Hunt (11) in the case of another Amphipod, Ampelisca. 
The actual swallowing action I could not definitely make out, but the reasons given for the suggestion that suction from the crop is the prime factor seem fairly sound. Parker and Mocquard have suggested a similar cause in Decapoda, but Borradaile (4) considers this doubtful, and suggests that the constrictor muscles of the œsophagus may conduct the process. The shortness of the latter organ in Corophium would seem to render such an explanation inapplicable in this case.

The life-cycle of Corophium volutator, as deduced from the measurementinvestigations of Whitby material, would seem to be essentially similar to that postulated by Blegvad (3) for several littoral Amphipoda of widely different genera: but the wintering period, when the animals are not breeding, is much longer. Most of the animals discussed by Blegvad stopped breeding in October, but began again in the following January. Further, it seemed that none of the wintering adult individuals lived long enough to start breeding again in the following spring, though the numbers so far studied are not sufficient to permit of so much stress being laid on this point at present. It has been clearly shown, however, that wintering adult females lose the hairs on their oostegites, and it would be extremely interesting to observe the re-development of these, if they did breed again. Mrs. Sexton drew my attention to the very interesting work of Unwin (21) on the isopod Asellus in this connection. In this animal it seems that the oostegites remain inconspicuous until the ecdysis accompanying fertilisation, when they expand to form large broodplates. Soon after the escape of the young, the female goes through another ecdysis, and the large oostegites are replaced by smaller processes. However, I do not think any similar phenomenon occurs in Corophium, as the lamellæ of the oostegites develop gradually as in other Amphipoda - the March sample showed females with the oostegites in all stages of development, becoming more advanced with increased size of the female (Table VIII). It is only the hairs that develop suddenly. Once present these hairs seem to remain until the end of the breeding season, as many females of the summer stock had fully developed brood pouches long after all the young had been extruded.

The fact that the breeding period of Corophium volutator is comparatively short for an amphipod is rather surprising in view of Ussing's observation that $C$. Bonelli breeds all the year round in certain Danish Fjords (22). The explanation is probably to be found in the fact that $C$. Bonelli lives on the Mytilus clusters just below low-tide mark and is therefore subject to much more uniform temperature conditions than C. volutator, dwelling on exposed flats which dry off every tide.

The fact that females are more numerous than males was known to Delage (8), and he gives the sex ratio as $3: 1$. This was precisely what I found at midsummer, but in March males were much more frequent, 
though still outnumbered by the females. I am at a loss to account for this, unless the last hatched broods each year contain a much greater proportion of males than the others. If this were the case, it might be that a detailed study of the development of $C$. volutator would throw light on problems of sex determination.

The extremely slow growth of the young during the winter is also exhibited in a lesser degree by Gammarus chevreuxi, a species which, under aquarium conditions at any rate, breeds all the year round. Of this species Sexton (Journ. Mar. Biol. Assoc., XV, 1928, p. 40) says : "The rate of development is affected to a large degree by temperature and to a lesser degree by the seasonal rhythm. Young hatched in the winter months take longer to reach maturity, even though the temperature be raised to summer conditions, than those hatched in the spring and summer." Bearing in mind what happens in C. volutator, it seems at least possible that this "seasonal rhythm" may be due simply to the cumulative temperature effect on thousands of generations of these brackish-water amphipods, under natural conditions.

\section{Note on the Morphology of the Gut Diverticula.}

In the course of this study of Corophium volutator it was discovered that the anterior dorsal gut diverticulum was bifid, but that small posterior diverticula of typical Gammaridean character were present. The dorsal diverticulum should be single in all Gammaridea, but paired in Hyperiidea and Caprellidea, according to all authorities whose works I have been able to consult. Thus Calman (6), Della Valle (9) and others.

This is interesting in view of the fact that Delage (8) advances the hypothesis that Corophium represents the common ancestral stock of the Caprellidea on the one hand, and the Gammaridea on the other. His view is based on a minute examination of the circulatory system of most of the main types of the old group Edriophthalma, including this particular species of Corophium. Stebbing, however, disposes of this view very effectively (18), arguing on general lines. But the bifid nature of the "Nackendrüse," unique among the Gammaridea so far as I have been able to ascertain, seems at first sight to lend support to Delage's view.

While Stebbing's arguments would seem to preclude the possibility of Corophium being the direct ancestor of the Caprellidea, the singly ostiate heart of Corophium, and the bifid nature of the "Nackendrüse" certainly seem to point to some sort of affinity. In this connection the evidence furnished by this disposition of the other gut diverticula in Corophium may be considered.

In the first place, Corophium is provided with a pair of posterior gut diverticula. Baldwin Spencer $(\mathbf{1} \boldsymbol{7})$ has pointed out the extraordinarily 
limited occurrence of these organs among higher Crustacea, though Claus has described somewhat similar organs in Copepoda. They are almost entirely confined to the Amphipoda Gammaridea, being only exceptionally present (Calman, 6) in Caprellidea and Hyperiidea. As Della Valle has pointed out, these organs are small in Corophium, but they are quite well developed, and agree with those of the more typical Gammaridea, as described by Wrzesniowski (23) in structure. The presence of these organs in Corophium is a serious objection to the hypothesis that the animal represents the common ancestral stock of the Gammaridea and Caprellidea by different lines of descent, as if this were the case one would have to postulate their gradual suppression in the latter group, whereas typical Gammaridean forms (e.g. Melita) are known in which the posterior gut diverticula are partially suppressed.

Corophium is not alone among the Gammaridea in having only one pair of hepato-pancreatic diverticula, though two pairs are more usual. In Caprellidea there is one pair only, but according to Calman (6) it is the ventrally situated pair which is rudimentary or absent, while in Corophium the well-developed hepato-pancreatic diverticula can clearly be seen to open into the mid-gut ventrally, and indeed are rather ventrally inclined to it throughout their length. Again, the evidence furnished by these organs in Corophium is in contradiction to Delage's hypothesis.

Taking all these facts into consideration, together with Stebbing's strong argument for regarding the Gammarus type as primitive, I suggest the substitution of the following for Delage's hypothesis : that Corophium is a secondarily modified amphipod, probably derived as an early independent offshoot from the evolutional series which started from Gammaridean stock, and culminated in the degraded Caprellids. On this view it is only necessary to suppose that the two anterior pairs of ostia, poorly developed in Caprellids, have disappeared altogether in the side line which gave rise to Corophium, while the balance of evidence gained from the disposition of the various gut diverticula is also maintained.

\section{Note on a Variation of Corophium volutator.}

In the female of this species, the first peduncular joint of the first antenna bears ventrally typically two stout spines direct obliquely forwards. Occasionally there are three or more of these spines either on one or both of the antennæ, as has been pointed out by Mercier (12), though I have never come across any similar spines in the male such as he also describes as varying in number. It is perhaps significant that Poisson and Legueux (14), in describing a variety of another Corophium species from the same locality, make no reference to any male spines in an otherwise rather full summary of Mercier's work. In the female, however, his 
account of the variation is certainly correct, though the further conclusions are somewhat doubtful. The number of individuals with more than the normal number of spines is said to be higher in brackish than in salt water, and it is claimed that this phenomenon "doivent rentrer dans la cadre de variation de place."

The numbers upon which Mercier's observations are based are very small, and he makes no mention of the time of year at which collections were made. As far as I can say at present, it appears that this variation is not due to differing salinity, but rather to some factor correlated with the much higher rate of metabolism of the summer stock. These may take no more than two months to reach maturity while the winter stock take six. Of 103 females of the summer stock, 25 showed the variation in a more or less marked degree, while 109 of the winter stock contained only 3 variants. Further, these samples, from the sample locality at Whitby, came from a place. where it appears that salinity rarely falls below ca. $20^{\circ} \%$.

\section{LITERATURE.}

1. Allen, E. J. On the Fauna and Bottom Deposits near the thirtyfathom line from the Eddystone grounds to Start Point. Journ. Mar. Biol. Assoc., N.S., Vol. V, 1897-99, p. 365.

2. Bate, C. Spence, and Westwood, J. O. A History of the British Sessile-eyed Crustacea. Vol. II. London, 1868.

3. Blegvad, H. On the Biology of some Danish Gammarids and Mysids. Repts. Danish Biol. Stn., Copenhagen, Vol. XXVIII. 1922.

4. Borradaile, L. A. On the Structure and Function of the MouthParts of Palæmonid Prawns. Proc. Zool. Soc. London, 1917, p. 37.

5. Bradley, J. Chester. Notes on two Amphipods of the genus Corophium from the Pacific Coast. Univ. of California. Publications in Zoology, Vol. 4, No. 4. 1908.

6. Calman, W. T. A Treatise on Zoology. Edited by Sir Ray Lankester, Part VII. Appendiculata. Third Fascicle. Crustacea. London, 1909.

7. Cannon, H. G., and Manton, Miss S. M. On the Feeding Mechanism of a Mysid Crustacean, Hemimysis Lamornce. Trans. Roy. Soc. Edin., Vol. LV, Pt. 1, No. 10. 1926-27.

8. Delage, Yves. Contribution à l'Étude de l'appareil circulatoire des Crustaces Edriophthalmes Marins. Archives de Zoologie Exp. et Gen., Tome IX, p. 1. 1881. 
9. Della Valle, A. Gammarini del Golfo di Napoli. Fauna und Flora das Golfes von Neapel Mongr., XX, 1, Vol. \& Atlas. 1899.

10. Gurney, Robert. Crustacean Fauna of the East Norfolk Rivers. Trans. Norfolk \& Norwich Nats. 1907.

11. Hunt, O. D. The Food of the Bottom Fauna of the Plymouth Fishing Grounds. Journ. Mar. Biol. Assoc., N.S., Vol. XIII, No. 3, p. 560. 1925.

12. Mercier, L. Variation de Place chez Corophium volutator (Pallas). Paris, C.R. Acad. Sci., Vol. 170, p. 410. 1920.

13. Orton, J. H. On the mode of feeding of the Hermit Crab Eupagurus Bernhardus and some other Decapoda. Journ. Mar. Biol. Assoc., N.S., Vol. XIV. 1926-27.

14. Poisson and Legueux. Corophium acutum Chevreuxi, var. n. Bull. Soc. Zool. Paris, 51, p. 520. 1926.

15. SARs, G. O. An Account of the Crustacea of Norway. Vol. I. Amphipoda. Christiana and Copenhagen, 1895.

16. Sexton, E. W. Moulting and Growth-stages of Gammarus, with descriptions of the Normals and Intersexes of $G$. chevreuxi. Journ. Mar. Biol. Assoc., N.S., Vol. XIII, No. 2, p. 340. 1924.

17. Spencer, W. Baldwin. On the Urinary organs of the Amphipoda. Quart. Journ. Micr. Sci., Vol. XXV, p. 183.

18. Stebbing, T. R. R. Report on the Amphipoda. Repts. Voy. "Challenger," Zool., XXIX. 1888.

19. Stebbing, T. R. R. Amphipoda: I. Gammaridea. Das Tierreich Leif. XXI. 1906.

20. Stephensen, K. Revideret Fortegnelse over Danmarks Arter af Amphipoda. Videns. Medd. f. Dansk Naturhist. For. Kjøbenhavn, Bd. 84, p. 107. 1927.

21. Unwin, ERnest E. Notes upon the reproduction of Asellus aquaticus. Journ. Linn. Soc. Lond. Zool., Vol. XXXIV.

22. Ussing, HJ., and Stephensen, K. Corophium Bonelli (M-Edw. ?) G. O. Sars, ny for Danmark, med Noter om andre Corophiumarter. Videns. Medd. f. Dansk Naturhist. For. Kjøbenhavn, Bd. '78, p. 69. 1924.

23. Wrzesniowski, A. Vorlaufige Mittheilungen uber einige Amphipoden, 4; Ueber den Darmkanal und seine Anhänge. Zool. Anz., 1-2, p. 511. 1878-79. 
